Relations industrielles

Industrial Relations

\title{
Rosenblum, Jonathan D., Copper Crucible: How the Arizona Miner's Strike Recast Labor-Management Relations in America
}

\section{Charles McCollester}

Volume 50, numéro 4, 1995

L'ergonomie et les relations industrielles

Ergonomics and Industrial Relations

URI : https://id.erudit.org/iderudit/051065ar

DOI : https://doi.org/10.7202/051065ar

Aller au sommaire du numéro

Éditeur(s)

Département des relations industrielles de l'Université Laval

ISSN

0034-379X (imprimé)

1703-8138 (numérique)

Découvrir la revue

Citer ce compte rendu

McCollester, C. (1995). Compte rendu de [Rosenblum, Jonathan D., Copper Crucible: How the Arizona Miner's Strike Recast Labor-Management Relations in America]. Relations industrielles / Industrial Relations, 50(4), 900-902.

https://doi.org/10.7202/051065ar

Tous droits réservés @ Département des relations industrielles de l'Université Laval, 1995
Ce document est protégé par la loi sur le droit d'auteur. L’utilisation des services d'Érudit (y compris la reproduction) est assujettie à sa politique d'utilisation que vous pouvez consulter en ligne.

https://apropos.erudit.org/fr/usagers/politique-dutilisation/ 
employment, and a discussion of "The Right to be Average." The rationale for the inclusion of a reprint of an admittedly interesting journal article by Schregle on German works councils is neither given nor obvious.

As an introduction to the book, the author quotes Dostoyevsky as to the negative effects of having one's work viewed as completely useless. Hopefully, my criticisms will not lead the reader to reach this conclusion on this book. For my own part, I judge the book to have sufficient virtues to offset its weaknesses, although I am tempted to recommend taking the author's advice in the Preface and read only Chapter 3 . My favourable opinion probably arises from a weakness on my own part for stimulating ideas, of which there is a plentiful supply in this book.

HOYT N. WHEELER

University of South Carolina

\section{Copper Crucible: How the Arizona Miner's Strike Recast Labor-Manage- ment Relations in America}

by Jonathan D. ROSENBLUM, Ithaca, N.Y., ILR Press, 1995, 257 p., ISBN 087546-331-2 (cloth), ISBN 0-87546-332-0 (pbk.).

An image haunts the book Copper Crucible. It's not like the spectre that once haunted Europe, though the Mexican American miners were at times during the history of their relationship with the Phelps Dodge corporation accused of being Communists. The image is a photograph that opens the book. A striker approaches an advancing line of state troopers through a cloud of tear gas. His arms are outstretched in an attitude of crucifixion and he is completely naked.

The subtitle of this excellent book makes a rather large claim. Historians might dispute the absolute centrality of the Phelps Dodge attack among the many powerful blows that both government and corporations directed at organized labour in the 1980 s, but Rosenblum makes a good case. According to the author, it was the implementation by Phelps Dodge of a union busting plan centered on the employment of permanent replacements which was developed by hardline management consultants out of the University of Pennsylvania's Wharton School that marked a turning point in U.S. labour relations.

Whether, it was really the PATCO strike, or the Eastern Airlines struggle (where management showed it was will- ing to destroy a company rather than share real power with its workforce), or the near liquidation of the great union stronghold of Pittsburgh, matters little. The copper strike revealed the extremes that companies would go to assure total domination of their workforce. The picture of Bobby Andazola walking naked toward the massed ranks of riot police from the Arizona Department of Public Safety shouting: "In the name of Lord God, Lord Jehovah, would you do this to your own brothers and sisters" stands as the archetypal image of U.S. labour in the 1980 s.

At the core of the book is a well written account of the bitter strike enriched by extensive interviews of participants from all sides of the dispute. This book is however more than an account of a particularly bitter labour confrontation. The author traces the long antiunion legacy of Phelps Dodge going back beyond the infamous Bigbee deportations of 1917, where twelve hundred workers organized by the IWW were taken by train across the New Mexico state line and simply dropped in the desert. In 1967, a long industry-wide copper strike was only settled by the personal intervention of President Lyndon Johnson. 
The fateful 1983 negotiations began well for the United Steel Workers Union as four out of the top five copper producers settled contracts that retained cost-of-living provisions (COLA). Only number two producer Phelps Dodge signalled its willingness to go to war demanding the linkage of COLA to the price of copper, substantial wage cuts, and concessions on benefits and medical care.

The evolution of union politics plays an important part in the story. From the IWW's Western Federation of Miners, to the Mine, Mill and Smelter Workers Union (accused of Communist domination in the 1940s), to the United Steelworkers of America who took over representation in the 1950 s, the primarily Mexican American workforce remained devoted to the labour organizations that provided a measure of protection from ethnic prejudice and dangerous working conditions on the job.

The 1983 strike took place in the context of a struggle for leadership inside the Steelworkers Union upon the death of President Lloyd McBride between Frank McKee, who was the head of the copper negotiations, and Canadian Lynn Williams. A contributing factor in McKee's inflexibility in responding to the real intentions of the company came from his desire to project a harder, more radical image in the union election than the pragmatic Williams. Believing in traditional trench warfare, McKee refused to sanction a corporate campaign that would target the banks that were carrying Phelps Dodge debt. When Williams won the election six months into the strike, he launched a corporate campaign that bloodied but did not shake Phelps Dodge.

Government played a large role in the union's defeat. Liberal Democrat Arizona Governor Bruce Babbitt removed the workers direct leverage when he sent in the National Guard to protect replacement workers from acts of vio- lence. Local sheriffs were virtually company agents. The coup de grâce to the union was delivered by regional NLRB director Milo Price, who Ronald Reagan had wanted to name as national NLRB chairman. Reagan backed off when the choice was protested by Teamster boss Frank Fitzsimmons. Price controlled the NLRB investigations and wrote a finding that totally exonerated Phelps Dodge of unfair labour practices despite ample evidence of coercion, anti-union bias and failure to bargain in good faith.

One of the strengths of the book is Rosenblum's ability to make the various characters come alive. Bobby Andazola, local union President Angel Rodriguez, organizer of the People's Clinic Dr. Jorge O'Leary, President of the Women's Auxiliary Fina Roman, bitter anti-union fighter Richard Moolick, union negotiator Frank McKee are all three dimensional characters.

The strike's social context is illuminated as, by and large, Catholics support the strike while the Mormons sided with the company. The Catholic Church's earlier resistance to a barbaric Phelps Dodge scheduling practice of 26 days on and 2 days off inspired the local priest to chastise his parishioners for accepting the practice: "There is only one difference between a whore in Nogales and a Phelps Dodge worker on the 26 and 2. At Phelps Dodge, you are better paid." The slow death of a community of three generations of copper workers is recounted here with compassion and sensitivity.

The book concludes with an important discussion of the conflict between union solidarity and democracy. An example discussed is between union democracy on the local and grassroots level where doubts about the strike were stifled by the Steelworker leadership's commitment to pattern bargaining. This "new solidarity" is a unity based on institutional needs which tends to have a logic and imperative of its own. La- 
bour unity or "defending the pattern" suppresses democratic participation. The "old solidarity" based on the community which was so amply demonstrated by the Mexican American strikers and their families is unable to overcome the power of a corporation supported by the forces of government. Strikers can only prevail if the public at large learns about the struggle and is moved to support it. Thus Rosenblum asserts that the unions "failed at one of their most basic tasks: educating the workers and the public about labour's needs".

Jonathan Rosenblum has written an elegant account of an important strike that has seriously impacted the state of labour/management relations in the United States. Its compact and readable style help make it an important contribution to the labour history of the 1980 s.

CHARLES MCCOLLESTER

Indiana University of Pennsylvania

\section{In Search of Participation: A Study of Some Successful Companies}

by J. S. SODI, Rama J. JOSHI, H. V.V. ChEllapPA, S. MASIlamani, Sarita A. KALIA, and Harinda SANHU, New Delhi, SHRI Ram Centre for Industrial Relations and Human Resources, 1995, 468 p.

The SHRI Ram Centre have produced an outstanding set of eight case studies on employee participation, a useful introductory chapter on employee participation and a helpful concluding summary of the case studies. As noted in the introductory chapter employee participation in industry has different forms in various countries of the world. The Indian version presented in this set of case studies is quite impressive in that it springs from strong communal values and also benevolent paternalism of founding families of outstanding Indian companies.

The companies selected and studied are quite exceptional in terms of fostering participation and most Indian organizations in the public and private sectors may not have very much employee participation. All these other Indian organizations can benefit from reading these case studies to see how employee participation can be achieved. Indeed North American industry can learn much also about effective employee relations. There has been so much emphasis recently on down sizing and re-engineering in North American industry that we can forget that we still depend on well motivated employees and managers to run the new companies.
Since the Indian case studies are developed in great depth it is not surprising that the authors emphasize the differences between the eight public and private companies presented. There are some differences between the companies in how they came to foster employee participation. National Fertilizers Limited (NFL) used joint committees and suggestion schemes to achieve productivity improvements. Hindustan Antibiotics Ltd. (HAL) used participation to increase "human potential" and thereby improve productivity. Fertilizers and Chemicals Travancore Ltd. (FACT) achieved efficiency and productivity through a "filial atmosphere". Bharat Electronics (BE) used quality circles to improve quality and upgrade technology. All the preceding are public sector companies but are still operated profitably in important industries.

Case studies were conducted in three private sector companies, Madura Coats, Tata Iron and Steel Company (TISCO), and Textile Equipment Ltd (TEL). In TISCO and TEL participative initiatives started with management but had strong employee acceptance. In Madura Coats there was considerable sharing of information and power between management and employees and much joint decision making. 